\title{
Effect of Organizational Justice Behaviors on Organizational Silence and Cynicism: A Research on Academics from Schools of Physical Education and Sports
}

\author{
Murat Erdoğdu \\ Department of Recreation Management, Faculty of Tourism, Necmettin Erbakan University, Turkey
}

Copyright $\bigcirc 2018$ by authors, all rights reserved. Authors agree that this article remains permanently open access under the terms of the Creative Commons Attribution License 4.0 International License

\begin{abstract}
In this research, it is aimed to examine the effect of organizational justice behaviors on organizational silence and cynicism based on the opinions of academics who serve in Schools of Physical Education and Sports, and Faculties of Sports Sciences. Research group consisted of academics from 22 different universities in Turkey. There are 320 people ( 245 males and 75 females) in the research group. Organizational justice scale, organizational silence scale, organizational cynicism scale and job performance scale are used as data collecting tools in the study. During the research, a model was tried to be created that reflected the correlation among organizational justice behaviors, organizational silence and cynicism the new model was examined by means of Structural Equation Model via Lisrel 8.7. According to the results, the higher the perception of organizational justice behaviors, the less the organizational cynicism. Moreover, there was a positive significant correlation between organizational silence and organizational cynicism.
\end{abstract}

Keywords Organizational Justice, Silence, Cynicism, Academic, Physical Education

\section{Introduction}

It can be mentioned that justice is one of the most important elements everywhere that human beings exist. Justice, which plays a role in regular improvement of individual and societal life, is also a remarkable element in the organizations where an individual spends a great portion of his daily life. It is possible to say that justice is one of the prerequisites for the organizations to improve and continue their existence. In this context, it is obvious that organizational justice is an important organizational behavior for an organization to exist and improve [1]. It may well be argued that organizational justice is an important and notable element for all organizations. In this sense, it is believed that organizational justice is a remarkable concept for educational organizations just as for business organizations.

It was accepted by social scientists that organizational justice has an importance as a basic necessity for effective functioning of the organizations and personal satiation of the employees and injustice should be seen as a problem in an organizational sense [2]. Based on this theory, many researches have been conducted, which emphasized the impact of perception of justice on employees. Studies on organizational justice put forth that concerns on justice can affect the attitudes and behaviors of the employees [3]. In this sense, when employees' perceptions about the organizational practices are fair, it causes them to exhibit positive attitudes and behaviors, while a perception of injustice may cause negative behaviors like theft and aggression, which makes it difficult for the organizations to reach its goals [4]. Moreover, perception of justice or the way of employees' perceiving justice affects job outputs related with performance like job satisfaction, organizational commitment, organizational silence, organizational cynicism, performance, and job motivation. Former studies showed that perception about the existence of organizational injustice caused negative results like a decrease in organizational commitment, organizational citizenship behavior and job performance, and on the other hand, it caused an increase in organizational cynicism and quitting rates $[5,6]$.

Perception of organizational justice is one of the important features of employees' behaviors. Because, employees, whose perception of organizational justice is 
positive, tend to exhibit positive behaviors, while employees, whose perception of organizational justice is negative, may tend to negative behaviors like decreasing levels of effort and trust in organization. In this sense, as an important area of study in effective functioning of the organizations, organizational justice has been studied extensively in recent years in organizational psychology, human resources management and organizational behavior fields [2]. Organizational justice can be defined as the perception of the employees about distribution, transaction, functioning and interaction in an organization. While creating this perception, employees identify various scales for themselves and use those scales in identifying whether or not they are treated fairly [7]. Organizational justice includes perceived justice about all of the social and economic mutual exchanges, and relationships of the individuals with their superiors, colleagues and the organization as a social system [8]. Although perception of organizational justice was mentioned in the literature as one of the determinants of organizational silence, scarcity of the studies, which were conducted on organizational justice and organizational silence together, drew attention [9].

Various kinds of dimensioning on organizational justice exist in the literature. At first, organizational justice was handled in two dimensions. One of them was distributive justice, defined as the fairness of the gains obtained by employees, and procedural justice, defined as the fairness of the procedures for determining those gains [10]. In later studies, organizational justice was examined in three dimensions as distributive, procedural, and interactional justice. Lastly, Greenberg [11] added new dimensions to perception of justice by dividing interactional justice into two as interpersonal justice (Related with distributive justice and with interpersonal attitudes regarding the level of politeness, value, and respect shown to the employees by the ones who determine gains) and informational justice (Related with procedural justice and with distribution of gains and how much information is given and how much explanation is made to employees about processes regarding these distributions) [3,12]. These dimensions of the organizational justice have importance at different levels for faith and attitude which employees develop about the organization and the administration [13]. In this research, organizational justice is handled in four dimensions as distributive, procedural, interpersonal and informational justice.

Organizational silence is a type of behavior, which can increase or decrease the organizational performance. Although organizational silence has a difficult style of expression sentimentally, it is an effective method in pointing out pleasing or displeasing situations in the organization [14]. Morrison and Milliken [15] defined silence as "the situation where the employees consciously keep their works, ideas, knowledge and thoughts regarding organizational development for themselves." In another definition, silence is defined as the situation where the employees are avoiding from oral or written statement about the behavioral, cognitive or emotional evaluations of their organizational matters to the people who can change or fix this situation [16]. According to Çolak [17], remaining silent issue should not be perceived as a passive behavior such as withdrawing of an individual, social silence or inertia. When silence is performed consciously, its active side steps in. Attitude of keeping opinions and ideas can be due to individual, cultural, social and sometimes biological factors. Remaining silent in organizational climate is actually hiding the ideas or opinions preferably or compulsorily in the face of an organizational problem or matter. Silence of the organizations occurs since employees do not make any contribution to their organizations [18]. According to Henriksen and Dayton [19], organizational silence is a group of little responses to significant problems that an organization faces. In a research conducted on public employees by Karacaoğlu and Küçükköylü [20], it was pointed out that silence was observed to be nonsignificant and attitudes of employees were rather weak regarding organizational cynicism.

Basic causes, which lead to organizational silence, are classified as individual, social and organizational factors. Individual factors are thoughts such as using shortcut, prejudices, maintaining status quo and keeping the existing situation. Social factors are climate of distrust and uncertainties on adaptation behavior and responsibility. Organizational factors are indisputable beliefs, unnecessary and incorrect information, and negligence of the interdependencies with other units related with the job [19].

It is observed that organizational silence has not been studied enough in the organizational behavior and management literature, despite its increasing importance in terms of both organizations and employees [21]. In recent years, beyond its meaning that individual have nothing to say or have no idea on a matter, the notion, that silence may be a phenomenon which contains deep and secret meanings inside, has widely been accepted [22]. If the employees give a message to their organizations or managers by remaining silent, then the meaning of this message should be interpreted thoroughly. Because there are potential risks that can affect the attitudes, behaviors or job gains of the employees in the background of these messages [23].

Organizational cynicism is one of the issues that have drawn attention in recent years especially in the field of organizational behavior. It is defined as the employees' beliefs that the employing organization lacks honesty and also defined as their negative attitudes towards the employing organization. Moreover, it emerges as a result of not fulfilling basic expectations such as sincerity, justice and honesty [24]. Cynicism, which was defined in the 
initial research studies as an attitude with basic symptoms such as displeasure and distrust to others, is equated in contemporary studies to disappointment that emerged as a result of failure of the institutions in meeting the high level expectations, which modern daily life offers [25, 26]. Andersson [27] defined cynicism as "both a general and specific attitude characterized by frustration, despair, and disappointment, and a negative feeling and distrust towards a person, group, ideology, social convention, or institution."

Organizational cynicism, defined as the individual's negative attitude towards the employing organization, emerges as a result of not fulfilling the basic expectations such as sincerity, justice and honesty by the organization [24]. In this context, since such employees, who have this kind of negative attitudes, can be found in almost all organizations, it is necessary to be aware of premises and outcomes of organizational cynicism in order to understand organization and employee efficiency [28]. When the employees perceive their organizations, organizational practices, and practices of the managers as fair, it urges them to display positive attitudes and behaviors towards the organization and their managers. On the other hand, when employees perceive their organizations as unfair, it urges them to exhibit negative behaviors against the organization and managers [29].

Brandes [30] defined organizational cynicism as a three-dimensional negative attitude towards the employing organization. These dimensions included; (1) belief that the organization was deprived of honesty (2) a negative feeling against the organization and depending on these, (3) derogatory and critical behaviors towards the organization [31]. In this context, the concept of organizational cynicism consists of three dimensions; cognitive (belief), affective (emotion) and behavioral (behavior).

If the employees believe that the practices in the organization and decisions made are fair and they have perceptions in this manner, this situation may be a motivating factor for them not to remain silent and talk [32]. Thus, relationship between silence and justice were investigated in different researches and it was put forward that employees having a high level of perception of justice moved away from silence behaviors [21, 32-35]. When the employees perceive that the distribution of gains in the organization, the interaction during this distribution, and methods and processes used to determine those gains are fair, it may lead them to express their ideas and opinions clearly and easily. In other words, ethical and fair behaviors that the organizational authority exhibit will diminish employees' personal fears on being victim and galvanize them into action to talk about potential issues and problems about the work and the organization. If the opposite is the case, then employees' tendency to remain silent may increase [34].

In the light of studies mentioned above, it can be said that perception of justice or injustice in the organization will be one of the important determinants of organizational silence and organizational cynicism. In order to test the hypotheses of the research, data collected from the interviews with academics from Schools of Physical Education and Faculties of Sports Sciences was used. The aim of this study is to identify the effect of organizational justice, which is regarded as one of the premises of organizational silence and cynicism in the literature and thought to have significant effects on employee attitude towards the organization, on academic organizations.

\section{Materials and Methods}

\subsection{Research Group}

Research group consisted of academics from Schools of Physical Education and Sports, and Faculties of Sports Sciences of 22 different universities in Turkey. There are 320 people (245 males and 75 females) in the research group. 10 participants are younger than 25 years old, 113 are in the range of 25-35 years old, 120 are in the range of $36-45$ years old, 53 are in the range of 46-55 years old and 15 are older than 56 years old. 34 participants have bachelor's degree, 94 have master's degree and 192 have doctoral degree. 140 participants serve as professors, associate professors or assistant professors and 180 participants serve as lecturers or specialists. 162 participants have less than 10 years of work experience and 158 participants have 11 or more years of work experience.

\subsection{Data Collection Tools}

\section{Organizational Justice Scale}

Organizational Justice Scale, which is used in many domestic or foreign publications as a tool to measure organizational justice and developed by Niehoff Moorman [36], is used in the research. Factors are called "Procedural Justice" and "Distributive Justice" respectively. Cronbach's alpha values are used in measuring internal consistency of the factors. These values are calculated as 0.95 for procedural justice and 0.91 for distributive justice. Scale consists of 20 questions. Expressions are graded with Likert scale as $1=$ strongly disagree, $2=$ disagree, $3=$ slightly agree, $4=$ agree and $5=$ strongly agree.

\section{Organizational Silence Scale}

In the research, the concept of organizational silence is measured by Organizational Silence Scale, which was developed by Dyne, Ang and Botero [37]. There are totally 15 statements in the scale. With these questions addressed to the employees, it is investigated to find out whether or not they remain silent and if they remain silent, which kind 
of silence behaviors they exhibit. Sub-dimensions existing in the scale are called as "Individual Silence" and "Relational Silence" respectively. Cronbach's alpha values are used in measuring internal consistency of the factors. These values are calculated as 0.93 for individual silence factor and 0.89 for relational silence sub-dimension. Within this research, 5-point Likert Scale is used for the organizational silence scale $(1=$ Never; $5=$ Always $)$.

\section{Organizational Cynicism Scale}

The scale, which was developed by Brandes [30], consists of 14 clauses in 3 sub-dimensions as cognitive, affective and behavioral. Statements in the scale are scored according to 5-level Likert type scale from 1 to 5 (1: never, 2: rarely, 3: sometimes, 4: often and 5: always). It is assumed that the higher the scores are in the scale, the more cynical behaviors participants have. The scale was adapted to Turkish by Erdost et al [38] and validity and reliability of it was fulfilled. Cronbach's alpha values are used to calculate internal consistency of the factors. These values are calculated as 0.91 for cognitive dimension, 0.93 for affective dimension and 0.86 for behavioral dimension.

\subsection{Data Collection}

Data for the research was collected between 1 June 2016 and 18 June 2017 after gaining necessary permission from the administrations of relevant schools and faculties. Data was collected by the researcher from relevant departments of twenty two different universities. Data was collected at Schools of Physical Education and Sports and Faculties of Sports Sciences in universities through research associates pursuing master's degrees and instructors serving at those institutions. Research associates and instructors who volunteered for data collection were informed about data collection process and written guidelines were provided. In this context, a convenient time was organized for the academics who volunteered to join the research, and they were asked to fill the scales at one session. The scales were applied at the same time to the academics who serve at the same departments. Academics filled the scales in their office rooms and application of the surveys was completed in about $10-15$ minutes.

\subsection{Data Analysis}

In order to reach main purpose of the research and to summarize the data obtained, the results are offered as arithmetic mean and standard deviation. Before the statistical analyses, all variables were examined in terms of univariate and multivariate normal distribution. Run statistics for univariate normal distribution put forward that kurtosis coefficients vary between -.53 and .69 and skewness coefficients vary between -.73 and .29. As univariate kurtosis and skewness values are smaller than 1, it can be said that they meet the relevant normality criterion $[39$, 40]. However, the test applied for multivariate normality among the variables was not determined as significant $\left(\chi^{2}=1.703, p>.05\right)$; standardized values (for multivariate kurtosis and skewness $)$ were found $.78(z=$ $1.680, p>.05)$ for the kurtosis, and $32.73(z=-.07, p>.05)$ for the skewness. According to these findings, it can be interpreted that multivariate normality hypotheses are verified. In the light of these values, Maximum Likelihood approach was used during the modeling at 0.05 level of significance.

In the study, a model reflecting the relationship among organizational justice behaviors, organizational silence and cynicism was formed. In the light of the literature, when variables related with the individuals' organizational justice behaviors are examined, it is observed that distributive justice, procedural justice and interactional justice drew attention. Again, it can be said that organizational silence has two dimensions as individual and relational, while organizational cynicism has three dimensions as affective, cognitive and behavioral. Accordingly, it can be said that distributive justice, procedural justice and interactional justice explain the perceptions of the organizational justice; individual and relational silence explain the organizational silence; affective, cognitive and behavioral cynicism explain the organizational cynicism.

In this study, in order to investigate the relationships among the organizational justice behaviors, organizational silence and organizational cynicism, following hypotheses were tested.

H1: The high perceptions of Academics from Schools of Physical Education and Sports about organizational justice will decrease their perceptions of organizational cynicism.

H2: The high perceptions of Academics from Schools of Physical Education and Sports about organizational justice will decrease their perceptions of organizational silence.

In different sources there are different pieces of information about which fit tests will be better for structural equation models and this problem maintains its currency. To test the validity of the model many fit indices are used. Out of these indices, most frequently used ones are; Chi-Square Goodness of Fit Test $\left(\chi^{2} / \mathrm{df}\right)$, CFI-Comparative Fit Index, GFI- Goodness-of-Fit Index, AGFI- Adjusted Goodness-of-Fit-Index, NFI- Normed Fit Index RMSEA-Root Mean Square Error of Approximation andSRMR-Standardized Root Mean Square Residual. Fit values regarding the tests mentioned above and used for model-data fit are shown on the following table. 
Table 1. Fit Criteria [41-45]

\begin{tabular}{|c|c|c|}
\hline Fit Indices & Perfect Fit & Acceptable Fit \\
\hline$\chi^{2} / d f$ & $0 \leq \chi^{2} / \mathrm{df} \leq 2$ & $2 \leq \chi^{2} / \mathrm{df} \leq 3$ \\
\hline$p$ value & $0.05<\mathrm{p} \leq 1.00$ & $0.01 \leq \mathrm{p} \leq 0.05$ \\
\hline$R M S E A$ & $0 \leq \mathrm{RMSEA} \leq 0.05$ & $0.05 \leq \mathrm{RMSEA} \leq 0.10$ \\
\hline SRMR & $0 \leq \mathrm{SRMR} \leq 0.05$ & $0.05 \leq \mathrm{SRMR} \leq 0.10$ \\
\hline NFI & $0.95 \leq \mathrm{NFI} \leq 1.00$ & $0.90 \leq \mathrm{NFI} \leq 0.95$ \\
\hline NNFI & $0.97 \leq \mathrm{NNFI} \leq 1.00$ & $0.95 \leq \mathrm{NNFI} \leq 0.97$ \\
\hline$C F I$ & $0.95 \leq \mathrm{CFI} \leq 1.00$ & $0.90 \leq \mathrm{CFI} \leq 0.95$ \\
\hline$G F I$ & $0.95 \leq \mathrm{GFI} \leq 1.00$ & $0.90 \leq \mathrm{GFI} \leq 0.95$ \\
\hline$A G F I$ & $0.90 \leq \mathrm{AGFI} \leq 1.00$ & $0.85 \leq \mathrm{AGFI} \leq 0.90$ \\
\hline
\end{tabular}

In order to test the fitting of the model, which was created in the research, to the data, values were calculated concerning all of the tests that were presented in the table.

\section{Results}

Descriptive statistics were presented on Table 2 concerning the scores that the academics (from the Schools of Physical Education and Sports) obtained from the scales which were administered to determine their perceptions of organizational justice, cynicism and organizational silence.

Table 2. Descriptive statistics concerning the perceptions of the academics from the schools of physical education and sports about organizational justice, cynicism and organizational silence $(n=320)$

\begin{tabular}{|c|c|c|c|}
\hline \multirow{2}{|c|}{ Scale } & $\bar{X}$ & Ss \\
\hline \multirow{3}{*}{ Organizational Justice } & Distributive Justice & 3.36 & 0.86 \\
\cline { 2 - 4 } & Procedural Justice & 3.21 & 1.05 \\
\cline { 2 - 4 } & Interactional Justice & 3.51 & 1.03 \\
\hline \multirow{3}{*}{ Organizational Cynicism } & Affective & 2.20 & 0.90 \\
\cline { 2 - 4 } & Cognitive & 2.44 & 0.84 \\
\cline { 2 - 4 } & Behavioral & 2.55 & 0.81 \\
\hline \multirow{2}{*}{ Organizational Silence } & Individual & 2.15 & 0.82 \\
\cline { 2 - 4 } & Relational & 3.37 & 1.07 \\
\hline
\end{tabular}

According to Table 2, interactional justice sub-dimension has the highest mean score concerning the perceptions about the organizational justice. The fact that sub-dimensions concerning the organizational cynicism are at low levels is another remarkable detail. Besides, it is seen that individual silence, one of the sub-dimensions of organizational silence, at a low level compared to relational silence. When the table is examined as a whole, in parallel with the research hypotheses, it is seen that the perceptions of the organizational justice are at a high level and the perceptions of organizational cynicism and the organizational silence are at low levels.

Hypotheses set to attain the purpose of the research are examined with Structural Equation Modeling that was made by Lisrel 8.7 program. The model that is created in accordance with the data obtained from the scales which were administered to determine the perceptions of the academics from the Schools of Physical Education and Sports about organizational justice, cynicism and organizational silence were presented in Figure 1.

When Figure 1 is examined, it will be observed that there is a negative significant correlation between the organizational justice behaviors and the organizational cynicism. Coefficient of correlation is -0.62 and $t$ value is -10.08 . Structural equation can be set as "organizational cynicism $=-0.62 *$ organizational justice". $R^{2}$ value for this equation is found 0.39 . According to these values, one point increase in organizational justice causes a 0.62 point decrease in organizational cynicism. So it can be argued that organizational cynicism will decrease when perception of organizational justice increases. 


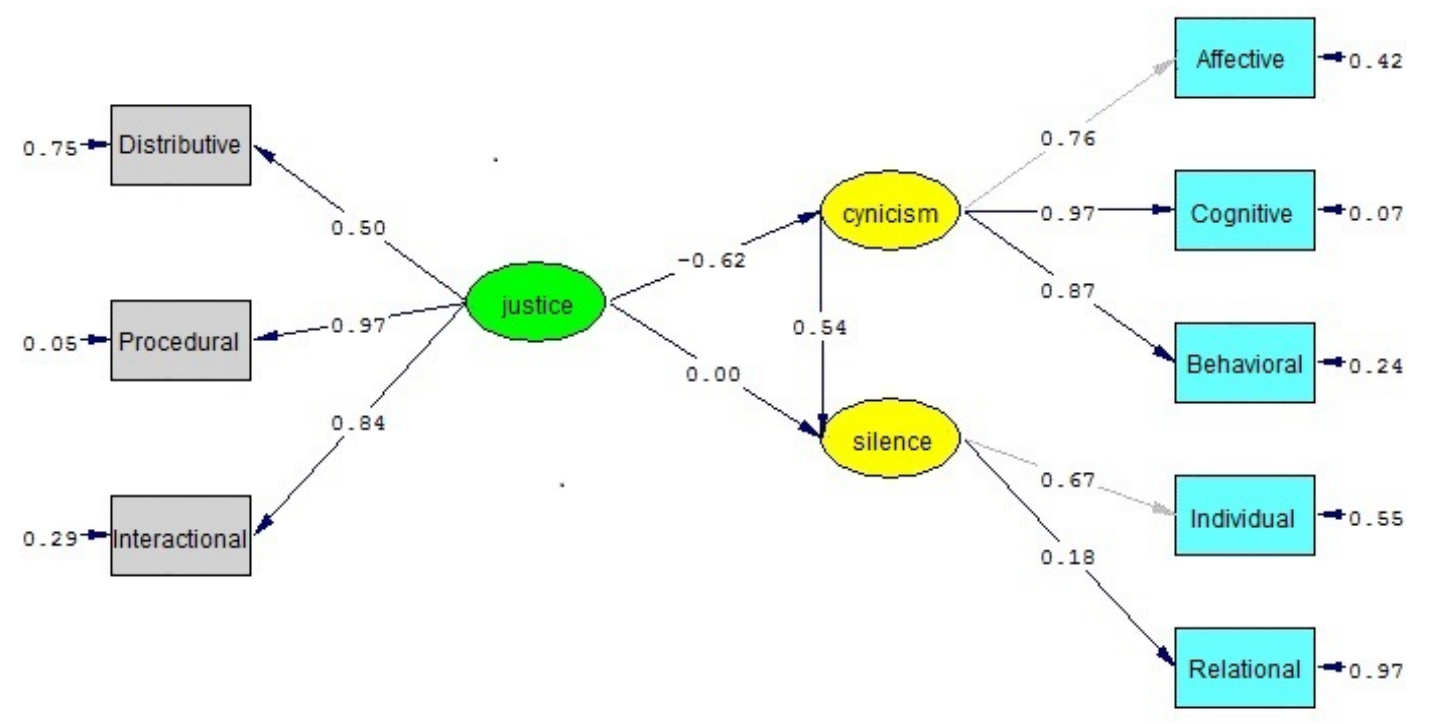

Chi-Square $=34.32, \mathrm{df}=17, \mathrm{P}-\mathrm{value}=0.00764, \mathrm{RMSEA}=0.057$

Figure 1. Structural equation modeling concerning the perceptions about organizational justice, organizational cynicism and organizational silence (Standard Coefficients)

Table 3. Fit values concerning the research model

\begin{tabular}{|c|c|c|c|c|c|c|c|c|c|c|c|}
\hline $\boldsymbol{n}$ & $\chi^{2}$ & $\boldsymbol{s d}$ & $\boldsymbol{p}$ & $\chi^{2} / \boldsymbol{s d}$ & $\boldsymbol{C F I}$ & $\boldsymbol{N F I}$ & NNFI & $\boldsymbol{G F I}$ & $\boldsymbol{A G F I}$ & $\boldsymbol{S R M R}$ & $\boldsymbol{R M S E A}$ \\
\hline 320 & 34.32 & 17 & 0.00 & 2.01 & 0.99 & 0.98 & 0.98 & 0.97 & 0.94 & 0.042 & 0.057 \\
\hline
\end{tabular}

In Figure 1, it will be observed that the correlation between organizational justice behaviors and organizational silence is not significant. However, there is a positive significant correlation between organizational silence and organizational cynicism. Coefficient of the correlation is 0.54 and $t$ value is 5.05 . This value can be interpreted that a one-point increase in organizational cynicism will cause a 0.54 point increase in organizational silence or conversely a one-point decrease in organizational cynicism will cause a 0.54 point decrease in organizational silence. Structural equation among organizational justice, organizational cynicism and organizational silence were found as "organizational silence $=0.54 *$ organizational cynicism + $0.00090 *$ organizational justice". $\mathrm{R}^{2}$ value for this equation is 0.29 .

All values concerning all of the tests in order to examine the model, which was set in the research, whether it fits to the data were presented on Table 3 .

When findings (Table 3 ) are compared with fit values presented on Table 1, it will be observed that a perfect fit exists between the model and the data. In line with these findings, it can be argued that the hypotheses concerning the tested model for the academics from the Schools of Physical Education and Sports are accepted. According to this, the high perceptions of the academics from the Schools of Physical Education and Sports about organizational justice decrease their perceptions of organizational cynicism and organizational silence.

\section{Discussion and Conclusions}

In the research, it is aimed to examine the effect of organizational justice behaviors on organizational silence and cynicism regarding the opinions of academics serving at Schools of Physical Education and Sports and Faculties of Sports Sciences. The research showed that interactional justice has the highest score among the mean scores concerning the perceptions of organizational justice; sub-dimensions of organizational cynicism are at low levels; besides, individual silence, which is one of the perceptions of organizational silence, is at lower level when compared to the relational silence. When mean scores of sub-dimensions concerning the scales used in the research are examined, in parallel with the hypotheses of the research, it was determined that the perceptions of organizational justice are at high levels whereas the perceptions of organizational cynicism and organizational silence are at low levels.

The model created was examined via Structural Equation Modeling concerning the results. As a result of this analysis, it was determined that there exists a negative and significant correlation between the organizational justice behaviors and the organizational cynicism. Results revealed that the organizational cynicism will decrease 
when the perception of the organizational justice behaviors increase.

There are few studies which investigated the relationship between the organizational justice and the organizational cynicism in the literature. In his study, in which he examined premises and results of the organizational cynicism, James [28] put forward that there was a negative correlation between the employees' perceptions of organizational justice and cynical attitudes.

In the study conducted by Fitzgerald [46], it was stated that individuals who had high perceptions of injustice towards the employing organizations would have more cynical attitudes towards their organizations. In the research conducted by Bernerth et al. [47], it was determined that a negative correlation existed between the organizational cynicism and distributive justice/interactional justice. In the same manner, in another research conducted by Kutanis and Çetinel [48] in order to reveal if there was a correlation between the employees' perceptions of injustice towards the organization and organizational cynicism, it was concluded that the academics who had negative perceptions of justice in general exhibited more cynical attitudes. The employees tend to pay more attention to decisions and matters about these dimensions, which have significant effects financially and socio-culturally, and react negatively when they perceive that those decisions and matters are not fair. When the practices in the organization are considered fair, improvement of the employees' positive attitudes will be possible. However, in a setting, where injustice is perceived, a climate of silence may be created in the organization since fear and anxiety of the employees arise and the opinions and concerns are not expressed easily, [49]. In this context, in case the employees perceive that prejudice and injustice exist at the organizational decisions and managerial activities, they may have negative feelings such as anger and disappointment $[28,46]$.

Examining justice at organizational level is important for both enterprises and other organizations. If the employees perceive their managers' approach as fair, then the organization will provide benefit in many ways. This situation increases the motivation of the employees, increases efficiency, and many similar benefits will be earned [50]. In the research that was conducted by Altınöz et al. [51], silence was an important factor in forming the cynicism. To remove both silence and cynicism, it was advised to handle administerial practices such as participating in decision making processes, increase of motivation and loyalty, effective leadership and justice carefully.

In the other studies [28,52], in which the elements affecting the organizational cynicism were investigated, various organizational factors such as increase of unjust behaviors in the organizations, decrease in organizational support, psychological breach of contract, increase in working hours and ineffective behaviors of the leaders in the organizations were identified as variables which had significant effects in creation of organizational cynicism attitudes.

In the research, it was determined that the correlation between the organizational justice behaviors and the organizational silence was not significant. Besides, there was a positive significant correlation between the organizational silence and the organizational cynicism. In the research conducted by Çaylak [53], a positive significant correlation was identified between the employees' organizational silence and organizational cynicism levels, and it was determined that causes of organizational silence had an effect on cynicism. On the other hand, also in the studies correspondingly supporting current findings and conducted by Demirtaş et al. [54]; Kalay et al. [55]; Nartgün and Kartal [56], it was determined that there was a positive significant correlation between organizational silence and organizational cynicism. This result can be interpreted that an increase in organizational cynicism will cause an increase in organizational silence, or on the contrary a decrease in organizational cynicism will cause a decrease in organizational silence as well.

The results obtained in similar researches [28, 46-48,50,52] also support our findings of this research. According to this, increases in unjust behaviors in the organizations have a remarkable effect on creation of organizational silence and cynicism.

In line with the literature, when the variables related with individuals' organizational justice behaviors are examined, it is observed that distributive justice, procedural justice and interactional justice come into prominence. Again, it is stated that organizational silence has two dimensions as individual and relational, organizational cynicism has three dimensions as affective, cognitive and behavioral. According to this; distributive justice, procedural justice and interactional justice expain perceptions of organizational justice, individual and relational silence explain organizational silence and affective, cognitive and behavioral cynicism explain organizational cynicism.

The results obtained from this research show that a perfect fit exists between the research model and the data. With these results, it can be stated that the high perceptions of the academics from the Schools of Physical Education and Sports about organizational justice decrease their perceptions of organizational cynicism and organizational silence. Regarding the results of the research, for the academics to be able to work with high efficiency and increase their loyalty to their employing institutions, it can be mentioned that fair decisions of the managers are important. Therefore it can be suggested that managers take necessary precautions in order to create a democratic working environment and make their decisions with a transparent concept of justice. Concerning the limitations of the research, a limited number of universities were reached and only quantitative methods were run. For 
further research, it is advised that sample size be enhanced and different models supported with qualitative methods be created.

\section{REFERENCES}

[1] O. Titrek. Okul türüne göre okullardaki örgütsel adalet düzeyi, Uluslararası İnsan Bilimleri Dergisi, Vol.6, No.2, 551-573, 2009.

[2] J. Greenberg. Organizational justice: Yesterday, today, tomorrow, Journal of Management, Vol.16, No.2, 399-432, 1990.

[3] T. A. Judge, J. A. Colquitt. Organizational justice and stress: The mediating role of work-family conflict, Journal of Applied Psychology, Vol.89, No.3, 395-404, 2004.

[4] C. D. Beugre. Understanding organizational justice and its impact on managing employees: An African perspective, The International Journal of Human Resource Management, Vol.13, No.7, 1091-1104, 2002.

[5] L. Francis, J. Barling. Organizational injustice and psychological strain, Canadian Journal of Behavioural Science, Vol.37, No.4, 250-261, 2005.

[6] Z. W. Ho, K. T. Chang. Simmelian ties, organizational justice and knowledge sharing in virtual workgroups, The 17th European Conference on Information Systems (ECIS 2009), 152-164, 2009.

[7] Y. Altınkurt, K. Yılmaz. Değerlere göre yönetim ve örgütsel adalet ilişkisinin ortaöğretim okulu öğretmenlerinin algılarına göre incelenmesi, Kuram ve Uygulamada Eğitim Yönetimi, Vol.16, No.4, 463-485, 2010.

[8] G. Yılmaz. İnsan kaynakları uygulamalarına ilişkin örgütsel adalet algısının çalışanların tutum ve davranışları üzerindeki etkisi, PhD Dissertation. İstanbul University Institute of Social Sciences, İstanbul, 2004.

[9] C. H. Meydan, K. Köksal, A. U. Kara. Örgüt içinde sessizlik: Örgütsel etik değerlerin etkisi ve adalet algisinin aracilik rolü, İktisadi ve İdari Bilimler Fakültesi Dergisi, Vol.17, No.3, 142-159, 2016.

[10] R. H. Moorman. Relationship between organizational justice and organizational citizenship behaviors: do fairness perceptions influence employee citizenship?, Journal of Applied Psychology, Vol.76, 845-855, 1991.

[11] J. Greenberg. The social side of fairness: interpersonal and informational classes of organizational justice, Russell Cropanzano (Ed.), Justice in the Workplace: Approaching Fairness in Human Resource Management, Lawrence Erlbaum Associates, Publishers, Hillsdale, New Jersey, 79-103, 1993.

[12] Ö. N. T. Özmen, Y. Arbak, P. Süral Özer. Adalete verilen değerin adalet algilari üzerindeki etkisinin sorgulanmasina ilişkin bir araştirma, Ege Akademik Bakış, Vol.7, No.1), 1733, 2007.

[13] Ö. Yeniçeri, Y. Demirel, Z. Seçkin. Örgütsel adalet ile duygusal tükenmişlik arasindaki ilişki: imalat sanayi çalişanlari üzerine bir araștirma, KMU İİBF Dergisi, Vol.11, No.16, 83-99, 2009.

[14] G. Bagheri, R. Zarel, M. N. Aeen. Organizational silence, Ideal Type of Management, Vol.1, 47-58, 2012.

[15] E. F. Morrison, F. J. Milliken. Organizational silence: a barrier to change and development in a pluralistic academy of management, The Academy of Management Review, Vol.25, No.4, 706-725, 2000.

[16] B. Bildik. Liderlik tarzlari, örgütsel sessizlik ve örgütsel bağlilik ilişkisi, (Unpublished Master's Thesis) Gebze Yüksek Teknoloji Enstitüsü Sosyal Bilimler Enstitüsü, Gebze, 2009.

[17] H. E. Çolak. Örgütsel sessizlik. in N. E. Özler, Örgütsel Davranışta Güncel Konular. Ekin Yayınları, 2015.

[18] F. Bowen, K. Blackmon, Spirals of silence: the dynamic effects of diversity on organizational voice, Journal of Management Studies Vol.40, No.6, 76-87, 2003.

[19] K. Henriksen, E. Dayton. Organizational silence and hidden threats to patient safety, Health Services Research, Vol.41, No.4, 1539-1554, 2006.

[20] K. Karacaoğlu, C. Küçükköylü. İşgören sessizliğinin örgütsel sinizme etkisi: kamu çalişanlari üzerine bir araştirma, Ege Akademik Bakış, Vol.15, No.3, 401-408, 2015.

[21] S. Tangirala, P. Ramanujam. Employee silence on critical issues: the cross level effects procedural justice climate, Personnel Psychology, Vol.61, 37-68, 2008.

[22] C. T. Brinsfield, M. E. Edwards, J. Greenberg. Voice and silence in organizations: Historical review and current conceptualizations. UK: Emerald Group Publishing Limited, 2009.

[23] L. Özdemir, S. S. Uğur. Çalışanların "örgütsel ses ve sessizlik" algılamalarının demografik nitelikler açısından değerlendirilmesi: Kamu ve özel sektörde bir araştırma, Atatürk Üniversitesi İktisadi ve İdari Bilimler Dergisi, Vol.27, No.1, 257-281, 2013.

[24] P. Brandes, R. Dharwadkar, J. W. Dean. Does organizational cynicism matter?: employee and supervisor perspectives on work outcomes, paper presented at the 36th Annual Meeting of the Eastern Academy of Management, Philadelphia PA, 1-34, 1999.

[25] L. M. Andersson, T. S. Bateman. Cynicism in the workplace: some causes and effects, Journal of Organizational Behavior, Vol.18, 449-469, 1997.

[26] P. Brandes, L. Castro, M. S. L. James, A. D. Martinez, T. A. Matherly, G. R. Ferris, W. A. Hochwarter. The interactive effects of job insecurity and organizational cynicism on work effort following a layoff, Journal of Leadership \& Organizational Studies, Vol.14, 233-247, 2008.

[27] L. M. Andersson. Employee cynicism: An examination using a contract violation framework, Human Relations, Vol.49, No.11, 1395-1418, 1996.

[28] M. S. L. James. Antecedents and consequences of cynicism in organizations: an examination of the potential positive and negative effects on school systems. a dissertation presented to the college of business, The Florida State University, 1-145, 2005. 
[29] S. Yürür. Örgütsel adalet, A. Keser, G. Yılmaz, S. Yürür. (Eds). Çaliş̧ma yaşaminda davraniş güncel yaklaşimlar, Birinci Basım, Kocaeli, Umut Yayınları, 167-207, 2009.

[30] P. M. Brandes. Organizational cynicism: its nature, antecedents, and consequences. Dissertation of doctor of philosophy, USA: The University of Cincinnati, 1997.

[31] I. B. Arabac1. The effects of depersonalization and organizational cynicism levels on the job satisfaction of educational inspectors, African Journal of Business Management, Vol.4, No.13, 2802-2811, 2010.

[32] C. Pillai R, A. Schriesheim, E. S. Williams. Fairness perceptions and trust as mediators for transformational and transactional leadership: a two-sample study, Journal of Management, Vol.25, No.6, 897- 933, 1999.

[33] S. Tangirala. Individual, group and leader influences on employee communication in high reliability contexts, Unpublished Doctorate Thesis, Indiana: Purdue University, 2006.

[34] K. Karacaoğlu, A. Cingöz. İş gören sessizliğinin kaynaği olarak liderlik davraniși ve örgütsel adalet algisi, 17. Ulusal Yönetim ve Organizasyon Kongresi, 21-23 Mayıs Eskişehir, Turkey, 698-705, 2009.

[35] C. Pinder Craig, K.H. Harlos. Employee silence: quiescence and acquiescence as response to perceived injustice, Research in Personnel and Human Resources Management, Vol.20, 331-369, 2001.

[36] B P. Niehoff, R. H. Moorman. Justice as a mediator of the relationship between methods of monitoring and organizational citizenship behavior. Academy of Management Journal, Vol.36, 527-556, 1993.

[37] L. V. Dyne, S. Ang, I. C. Botero. Conceptualizing employee silence and employee voice as multidimensional constructs, Journal of Management Studies, Vol.3, No.4, 1359-1392, 2003.

[38] E. H. Erdost, K. Karacaooğlu, M. Reyhanoğlu. Örgütsel sinizm kavrami ve ilgili ölçeklerin Türkiye'deki bir firmada test edilmesi”, 15. Ulusal Yönetim ve Organizasyon Kongresi Bildiriler Kitab1, Sakarya Üniversitesi, 514-524, 2007.

[39] J. Pallant. SPSS Survival Manual: A Step by Step Guide to Data Analysis Using the SPSS Program. Berkshire, England: Open University Press/McGraw-Hill Education, 2010.

[40] Ș. Büyüköztürk. Sosyal Bilimler İçin Veri Analizi El Kitab1 [Data Analysis Handbook for Social Studies $10^{\text {th }}$ Ed.), Ankara: PEGEM, 2009.

[41] K. Schermelleh-Engel, H. Moosbrugger, H. Müller. Evaluating the fit of structural equation models: Tests of significance and descriptive goodness-of-fit measures. Methods of Psychological Research Online, Vol.8, 23-74, 2003.

[42] M. W. Browne, R. Gudeck. Alternative ways of assessing model fit. In K. A. Bollen \& J. S. Long (Eds.), Testing structure equation models, Newbury Park, CA: Sage, 1361621993.

[43] R. C. MacCallum, M. W. Browne, H. M. Sugawara. Power analysis and determination of sample size for covariance structure modeling, Psychological Methods, Vol.1, No.2, 130-49, 1996.

[44] L. T. Hu, P. M. Bentler. Cutoff criteria for fit indexes in covariance structure analysis: conventional criteria versus new alternatives, Structural Equation Modeling, Vol.6, No.1, $1-55,1999$.

[45] B. M. Byrne. Structural equation modeling with EQS and EQS/Windows. Thousand Oaks, CA: Sage Publications, 1994.

[46] M. Fitzgerald. Organizational cynicism: its relationship perceived organizational injustice explanatory style, A Dissertation Presented to the Division of Research and Advanced Studies of University of Cincinnati, 1-70, 2002.

[47] J. B. Bernerth, A. A. Armenakis, H. S. Feild, H. J. Walker. Justice, cynicism, and commitment: a study of important organizational change variables, Journal of Applied Behavioral Science, Vol.43, 303-326, 2007.

[48] R. Ö. Kutanis, E. Çetinel, Adaletsizlik algisi sinisizmi tetikler mi?: bir örnek olay, Dumlupınar Üniversitesi Sosyal Bilimler Dergisi, Vol.26, 185-197, 2010.

[49] A. Naktiyok, S. Kızıl, M. K. Timuroğlu, Çalișanlarin adalet algisi sessizliklerini etkiler mi? öyp ve diğer araştirma görevlileri açisindan karșilaștirmali bir araștirma, Süleyman Demirel Üniversitesi İktisadi Ve İdari Bilimler Fakültesi Dergisi, Vol.20, No.4,197-219, 2015.

[50] M. Tuna. Örgütsel adalet: kamu ve özel sektör kuruluşlarinda bir araştirma, The Journal of Academic Social Science Studies, Vol.6, No.8, 997-1023, 2013.

[51] M. Altınöz, D. Çakıroğlu, S. Çöp, E. Kahraman. Örgütsel sessizliğin örgütsel sinizm üzerine etkisi: bir alan araştirmasi, Electronic Journal of Vocational Colleges, Vol.7, No.2, 73-76, 2017.

[52] A. J. A. M. Naus. Organizational cynicism: on the nature, antecedents, and consequences of employee cynicism toward the employing organization, Maastricht University, $1-144,2007$.

[53] E. Çaylak. Hemşirelerde örgütsel sessizlik ile örgütsel sinizm ve işten ayrılma niyeti arasındaki ilişki, Master's Thesis, Sağlik Bilimleri Enstitüsü, Atatürk Üniversitesi, Erzurum, 2014.

[54] Z. Demirtaş, T. Y. Özdemir, Ö. Küçük. Okullarin bürokratik yapisi, örgütsel sessizlik ve örgütsel sinizm arasindaki ilişki, Kuram ve Uygulamada Eğitim Yönetimi, Vol.22, No.2, 193-216, 2016.

[55] F. Kalay, A. Oğrak, Z. N. Nişanc1. Mobbing, örgütsel sessizlik ve örgütsel sinizm ilişkisi: Örnek bir uygulama. Kastamonu University Journal of Economics \& Administrative Sciences Faculty, Vol. 4, No. 2, 127-143, 2014.

[56] Ş. S. Nartgün, V. Kartal. Öğretmenlerin örgütsel sinizm ve örgütsel sessizlik hakkındaki görüşleri. (Teachers' perceptions on organizational cynicism and organizational silence). Bartın Üniversitesi Eğitim Fakültesi Dergisi, Vol.2, No.2, $47-67,2013$. 